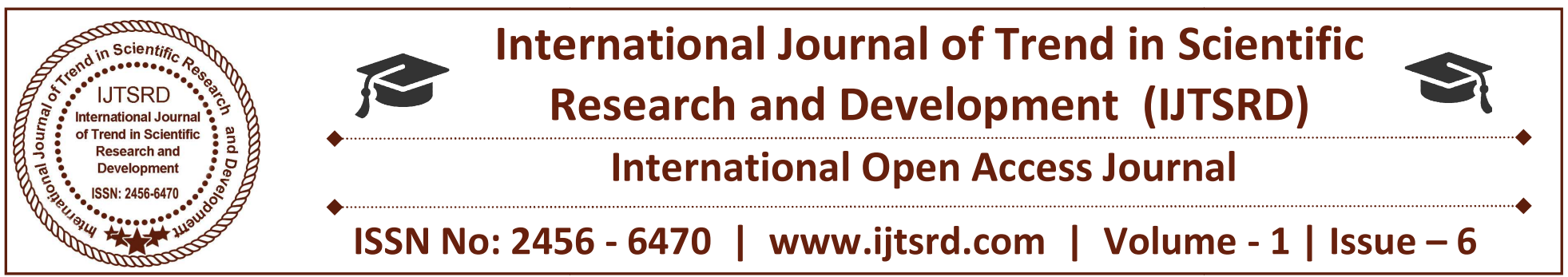

\title{
In vitro anti-oxidant and anti-carcinogenic properties of Calotropis gigantea (L.) R. Br. in its methanolic stem extracts
}

\author{
Jim Thomas \\ Department of Biotechnology, \\ Muthayammal College of Arts and \\ Science, Rasipuram, Tamil Nadu
}

\author{
M. Suresh Kumar \\ Department of Zoology, \\ Muthayammal College of Arts and \\ Science, Rasipuram, Tamil Nadu
}

\author{
T. Selvan Kumar \\ Department of Biotechnology, \\ Mahendra College of Arts and \\ Science, Namakkal, Tamil Nadu
}

\section{ABSTRACT}

Medicinal plants have been an important part in the healthcare management using traditional medicine. They have contributed to the generation of novel drugs and in the treatment of various diseases. Cellular damage caused by reactive oxygen species (ROS) has been implicated in several diseases. Cancer is a major public health burden in both developed and developing countries. Anticancer activity is the effect of natural and synthetic or biological and chemical agents to reverse, suppress or prevent carcinogenic progression. Several synthetic agents are used to cure the disease but they have their toxicity and hence the research is going on to investigate the plant derived chemotherapeutic agents. Natural antioxidants have significant importance in human health. Calotropis gigantea, a medicinal plant has been reported to possess different therapeutic properties. In the present study, in vitro antioxidant status and anti carcinogenic properties of $C$. gigantea were analysed using most commonly accepted assays that is reducing power assay and DPPH assay. The in vitro cytotoxic activity of $C$. gigantea extract using the MTT assay against MCF-7 and PC-3 cell lines.

Keywords: Calotropis gigantea, in vitro antioxidant activity, in vitro cytotoxic activity, cell lines, MTT assay

\section{INTRODUCTION}

Medicinal plants have known to play an important role in health care. Plant based drugs or formulations are mainly used in Ayurveda for treating various human ailments because they contain the components of therapeutic value (WHO, 1993). Since ages, medicinal plants have been used by human beings for their therapeutic potential and this has led to the discovery of novel drugs against varied diseases. World Health Organization (WHO) has stated that more than $80 \%$ of the world's population depend on traditional medicine for their primary healthcare needs (Pierangeli et al., 2009). Higher plants continue to play an important role as sources of bioactive compounds for the maintenance of human health. Reports state that plants are a reservoir of effective chemotherapeutants, which are non-phytotoxic, more systemic and easily biodegradable (Vyas, 1999; Kaushik et al., 2002; Chaman Lal and Verma, 2006).

Nevertheless, free radicals can also be damaging because of their reaction with various biological molecules namely lipids, proteins and deoxyribonucleic acids resulting in the imbalance between oxidants and antioxidants. Although the body is protected by natural antioxidants, there is always a requirement of antioxidants from natural sources (Rimbach et al., 2005). Phenolic compounds possess strong antioxidant activity and protect the cells against the free-radicals induced oxidative damage (Kahkonen et al., 1999). They are also known as radical scavengers, metal chelators, reducing agents, 
hydrogen donors, and singlet oxygen quenchers (Proestos et al., 2006).

Antioxidants are those compounds which terminate the attack of free radicals and thereby reduce the risk of oxidative stress disorders (Rice-Evans et al., 1996). They possess free radical chain reaction breaking properties. Enzymes such as super-oxide dismutase, catalase and antioxidant compounds viz. ascorbic acid, tocopherol, phenolic acids, polyphenols, flavonoids and glutathione protect organisms from oxidative stress. Antioxidative defence mechanisms are the most effective path to eliminate and diminish the action of free radicals which cause the oxidative stress. Plants have antioxidant activities that can be helpful in reducing such free radical induced tissue injury (Kanatt et al., 2007).

Cancer is a group of diseases which are characterized by uncontrolled growth and spread of abnormal cells, which if not controlled, can result in death. They are characterized by abnormal multiplication of cells. They are the second cause of mortality after cardiovascular diseases in developed countries and the third after infectious and cardiovascular diseases in developing countries (Bieche, 2004; Mbaveng et al., 2011).

Calotropis gigantea (L.)R.Br. are glabrous or hoary, lactiferous shrubs or small trees, about 3-4 m tall commonly known as the swallow-wort or milkweed. Its stems are erect, up to $20 \mathrm{~cm}$ in diameter. The leaves are broadly elliptical to oblong obviate in shape, with the size of $9-20 \mathrm{~cm} \times 6-12.5 \mathrm{~cm}$ but subsessile. The cymes are $5-12.5 \mathrm{~cm}$ in diameter. The inflorescence stalk is between $5-12 \mathrm{~cm}$ long, the stalk of an individual flower is $2.5-4 \mathrm{~cm}$ long. Sepal lobes are broadly egg shaped with a size of 4-6 mm x 2-3 $\mathrm{mm}$. Petal is $2.5-4 \mathrm{~cm}$ in diameter. In the present study, the in vitro antioxidant and cytotoxic activity of the $C$. gigantea methanolic stem extract were studied using the MTT assay against MCF-7 and PC-3 DLA.

\section{Materials and Methods}

\section{Sample Preparation}

Healthy parts of stem were shade dried and powdered from samples of $C$. gigantea (L.) R.Br. collected from Namakkal District, Tamil Nadu. Methanolic solvent stem extract was prepared using Soxhlet extraction method. The process was carried out overnight to obtain the necessary extract which was concentrated using a rotary evaporator and stored at $4^{\circ} \mathrm{C}$ for further use.

\section{Reducing Power Assay}

A method developed by Oyaizu, 1986 for reducing power test was used. The above sample including extract together with Ascorbic acid solutions were spiked with $2.5 \mathrm{ml}$ of phosphate buffer $(0.2 \mathrm{M}, \mathrm{pH} 6.6)$ and $2.5 \mathrm{ml}$ of $1 \%$ potassium ferricyanide. The mixture was then kept in a $50^{\circ} \mathrm{C}$ water-bath for $20 \mathrm{~min}$. The resulting solution was then cooled rapidly, spiked with $2.5 \mathrm{ml}$ of $10 \%$ trichloroacetic acid, and centrifuged at $3000 \mathrm{rpm}$ for $10 \mathrm{~min}$. The supernatant $(5 \mathrm{ml})$ was then mixed with $5 \mathrm{ml}$ of distilled water and $1 \mathrm{ml}$ of $0.1 \%$ ferric chloride. The absorbance at $700 \mathrm{~nm}$ was then detected after reaction for $10 \mathrm{~min}$. The higher the absorbance represents the stronger the reducing power. The reducing power assay was expressed in terms of Ascorbic acid equivalent per gram of dry weight basis.

\section{DPPH Activity}

DPPH radical scavenging activity was carried out by the method of Molyneux (2004). To $1.0 \mathrm{ml}$ of 100.0 $\mu \mathrm{M}$ DPPH solution in methanol, equal volume of the sample in methanol of different concentration was added and incubated in dark for 30 minutes. The change in coloration was observed in terms of absorbance using a spectrophotometer at $514 \mathrm{~nm} .1 .0$ $\mathrm{ml}$ of methanol instead of test sample was added to the control tube. The different concentration of ascorbic acid was used as reference compound. Percentage of inhibition was calculated from the equation [(Absorbance of control - Absorbance of test)/ Absorbance of control)] $\times 100$. $\mathrm{IC}_{50}$ value was calculated using Graph pad prism 5.0.

\section{MTT Assay}

\section{Cell Lines and Culture Medium}

MCF-7 (Human, Breast cancer) \& PC - 3 (Human prostate cancer cell line) cell cultures were procured from National Centre for Cell Sciences (NCCS), Pune, India. Stock cells were cultured in Dulbecco's modified Eagle's medium (DMEM). Medium was supplemented with $10 \%$ inactivated Fetal Bovine Serum (FBS), penicillin (100 IU/ml), streptomycin $(100 \mathrm{~g} / \mathrm{ml})$ and amphotericin B $(5 \mathrm{~g} / \mathrm{ml})$ in an humidified atmosphere of $5 \% \quad \mathrm{CO}_{2}$ at $37^{\circ} \mathrm{C}$ until confluent. The cells were dissociated with TPVG solution $(0.2 \%$ trypsin, $0.02 \%$ EDTA, $0.05 \%$ glucose 
in PBS). The stock cultures were grown in $25 \mathrm{~cm}^{2}$ culture flasks and all experiments were carried out in 96 microtitre plates (Tarsons India Pvt. Ltd., Kolkata, India).

\section{Preparation of Test Solutions}

For cytotoxicity studies, each weighed test drugs were separately dissolved in distilled DMSO and volume was made up with DMEM supplemented with $2 \%$ inactivated FBS to obtain a stock solution of $1 \mathrm{mg} / \mathrm{ml}$ concentration and sterilized by filtration. Serially two fold dilutions were prepared from this for carrying out cytotoxic studies.

\section{Determination of Cell Viability by MTT Assays}

The monolayer cell culture was trypsinized and the cell count was adjusted to $1.0 \times 10^{5}$ cells $/ \mathrm{ml}$ using medium containing $10 \%$ FBS and were used for the determination of cell viability by MTT assays as described by Francis and Rita (1986) respectively. The absorbance was measured using a microplate reader at a wavelength of $540 \mathrm{~nm}$. The percentage growth inhibition was calculated using the following formula and concentration of test drug needed to inhibit cell growth by $50 \% \quad\left(\mathrm{CTC}_{50}\right)$ values is generated from the dose-response curves for each cell line.

$$
\% \text { Growth inhibition }=100-\frac{\text { Mean OD of individual test group }}{\text { Mean OD of control group }} \times 100
$$

\section{Results and discussion}

\section{In vitro antioxidant activity}

There is increasing evidence that antioxidants may be useful in preventing the deleterious consequences of oxidative stress and there is increasing interest in the protective biochemical functions of natural antioxidants contained in spices, herbs and medicinal plants (Osawa, 1994; Noda et al., 1997).

\section{Reducing power Assay}

There are several other mechanisms by which antioxidants can act. One of them is by scavenging of reactive oxygen and nitrogen free radicals. There are many different experimental methods by which the free radical scavenging activity can be estimated. One such method, by which total free radical scavenging can be evaluated, is by determining their efficiency to scavenge DPPH radicals. This method is based on the reduction of DPPH, a stable free radical and any molecule that can donate an electron or hydrogen to DPPH can react with it and thereby bleach the DPPH absorption. Because of its odd electron, DPPH gives a strong absorption maximum at $514 \mathrm{~nm}$ by visible spectroscopy (purple colour). As the odd electron of the radical becomes paired off in the presence of a hydrogen donor, that is, a free radical scavenging antioxidant, the absorption strength is decreased and the resulting decolorization is stoichiometric with respect to the number of electrons captured (Blios, 1958) therefore when the $C$. gigantea methanol extract were tested for the DPPH free radical scavenging ability, the methanolic extract of $C$. gigantea at showed strong radical scavenging activity with Inhibition percentage of $196.38 \mu \mathrm{g} / \mathrm{ml}$ (Table 2, Fig. 1). Whereas the reducing power assay shows the inhibition percentage as $505.14 \mu \mathrm{g} / \mathrm{ml}$ (Table 1, Fig. $1)$.

\section{In vitro anticancer activity}

In this study, the cytotoxicity of the cell lines used was found to be increasing with increasing extract concentration. There was a reduction in viability i.e., $16 \%$ and $27 \%$ in the case of PC 3 and MCF7 cell lines respectively. This result was in hand with the previous reports. In spite of the development in the cancer therapies, the mortality rate associated with cancer has always stayed high. Thus, with regard to the present scenario and the toxic side effects associated with the available treatments, there is a need for alternative methods which have higher efficacy and lesser toxic side effects. Plants are considered as the best substitute and many have been evaluated in order to discover novel, potential anticarcinogenic compounds with no toxic effects (Gullett et al., 2010; Shah et al., 2013). Two main strategies adopted for the selection of plants species used in anticarcinogenic drug discovery are random screening and ethno medicinal knowledge. The second approach is the use of plants of traditional medical systems like herbalism and folklore (Pieters and Vlietnick, 2005). The cell lines obtained from tumors help to investigate tumor cells in a simplified and controlled environment (Makari et al., 2008). In the cancer drug discovery program, instead of mass screening of plant species, methods based on ethnobotanical and ethnopharmacological 
International Journal of Trend in Scientific Research and Development (IJTSRD) ISSN: 2456-6470

data would be more economical and beneficial for identifying potential anticancer molecules (Merghoub et al., 2009). Investigating the cellular growth control mechanisms have helped to understand carcinogenesis and to identify compounds with specific antitumor activities. Therefore, important preliminary data are provided by cytotoxicity screening models which help to select plant extracts with potential antitumor properties for future studies (Cardellina et al., 1999).

Tables and Figures

\begin{tabular}{|c|c|c|c|}
\hline Concentration & OD Value & \% IC $\mathrm{IC}_{50}$ & \multirow{2}{*}{$\mathbf{5 0 5 . 1 4}$} \\
\cline { 1 - 3 } $\mathbf{5 0}$ & 0.193 & 32.19 & \\
\hline $\mathbf{1 0 0}$ & 0.198 & 35.61 & \\
\hline $\mathbf{2 5 0}$ & 0.218 & 49.31 & \\
\hline $\mathbf{7 5 0}$ & 0.225 & 59.10 & \\
\hline $\mathbf{1 0 0 0}$ & $\mathbf{0 . 2 3 7}$ & $\mathbf{6 2 . 3 2}$ & \\
\hline
\end{tabular}

Table 1 : Reducing power Assay

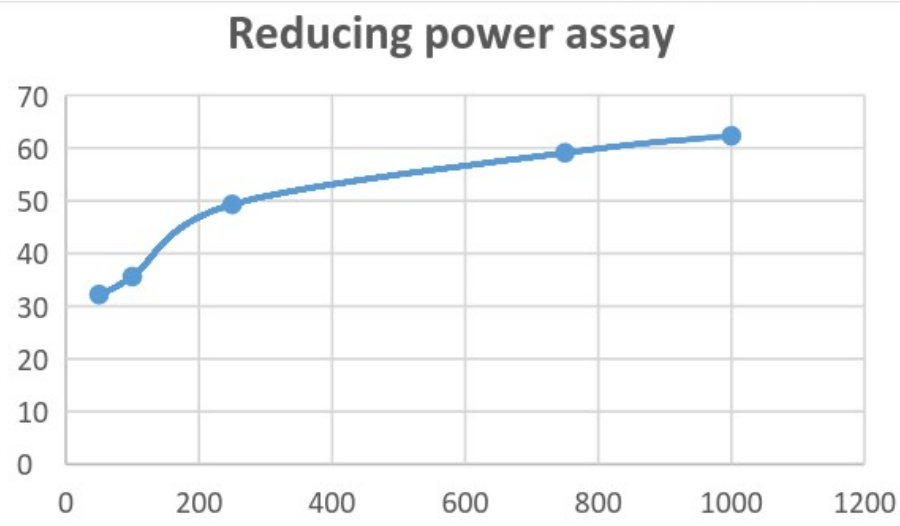

Figure 1: RP Assay of antioxidant activity of C.gigantea methanolic stem extract - graph

\begin{tabular}{|c|c|c|c|}
\hline Concentration & OD Value & \% IC IC $_{50}$ & \multirow{2}{*}{196.38} \\
\hline 50 & 0.189 & 40.00 & \\
\hline 100 & 0.192 & 42.20 & \\
\hline 250 & 0.217 & 60.74 & \\
\hline 750 & 0.219 & 62.22 & \\
\hline 1000 & 0.225 & 66.66 & \\
\hline
\end{tabular}

Table 2 : DPPH Assay 


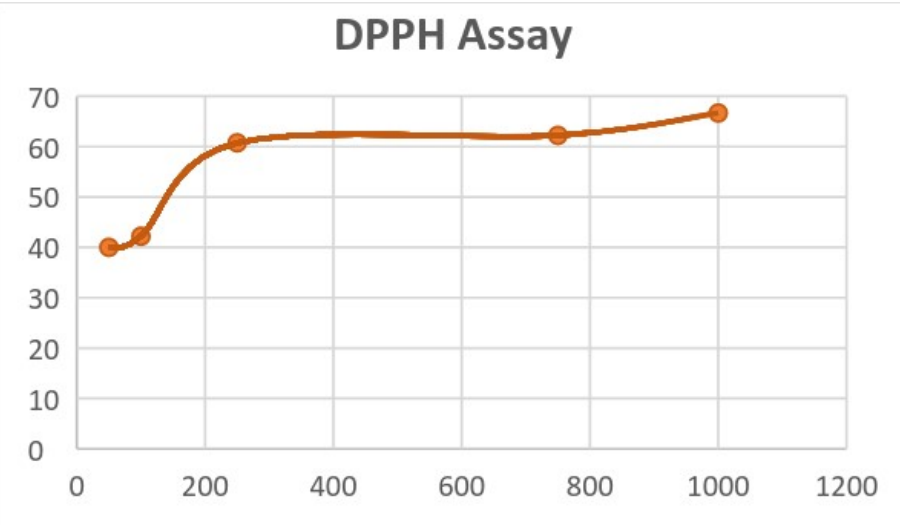

Figure 2: DPPH Assay of antioxidant activity of C.gigantea methanolic stem extract - graph

\begin{tabular}{|c|c|c|c|c|}
\hline Concentration & OD Value & $\% \mathrm{CTC}_{50}$ & $\mathrm{CTC}_{50}$ & Cell Viability \\
\hline Control & 0.573 & - & \multirow{6}{*}{375.04} & - \\
\hline 50 & 0.373 & 34.90 & & 65.10 \\
\hline 250 & 0.328 & 42.76 & & 57.24 \\
\hline 500 & 0.254 & 55.67 & & 44.33 \\
\hline 750 & 0.186 & 67.53 & & 32.47 \\
\hline 1000 & 0.095 & 83.42 & & 16.58 \\
\hline
\end{tabular}

Table.3 Anti tumor activity of C.gigantea methanolic stem extract against PC3cell line

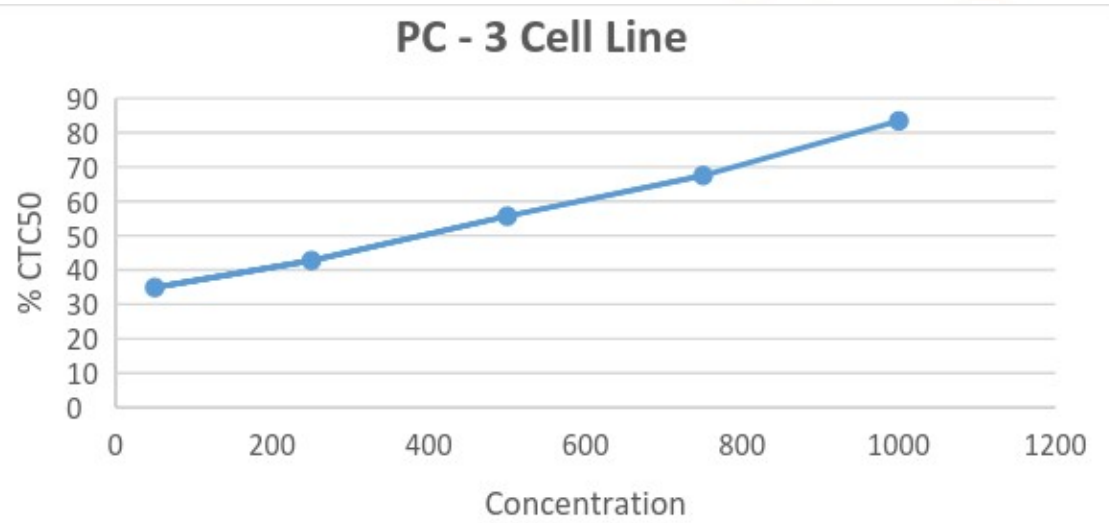

Figure 3: Anti tumor activity of $C$.gigantea methanolic stem extract against PC cell lines - graph 
International Journal of Trend in Scientific Research and Development (IJTSRD) ISSN: 2456-6470

\begin{tabular}{|c|c|c|c|c|}
\hline Concentration & OD Value & $\% \mathrm{CTC}_{50}$ & $\mathrm{CTC}_{50}$ & Cell Viability \\
\hline Control & 0.573 & - & \multirow{6}{*}{598.17} & - \\
\hline 50 & 0.461 & 19.54 & & 80.46 \\
\hline 250 & 0.377 & 34.20 & & 65.80 \\
\hline 500 & 0.301 & 47.46 & & 52.54 \\
\hline 750 & 0.268 & 53.22 & & 46.78 \\
\hline 1000 & 0.157 & 72.60 & & 27.40 \\
\hline
\end{tabular}

Table.4 Anti tumor activity of $C$.gigantea methanolic stem extract against MCF7 cell lines

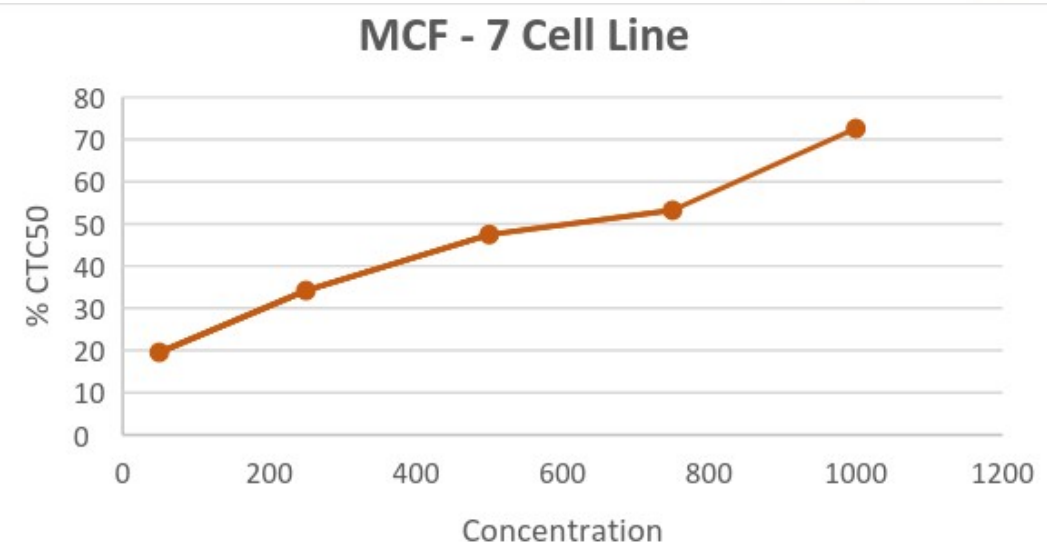

Figure 3: Anti tumor activity of $C$.gigantea methanolic stem extract against PC cell lines - graph

\section{Conclusion}

The methanolic extract of $C$. gigantean was found as an effective antioxidant agent with free reducing activity as well as DPPH activity. The extract exhibited a significant antitumor activity against the cell lines tested. There was a reduction of viability to $16 \%$ and $27 \%$ in case of Cell line PC3 and MCF7 respectively.

\section{References:}

1) Blios MS. Antioxidant Determinations by the Use of a Stable Free Radical. Nature 1958; 181: 11991200 .

2) C. Proestos, I.S. Boziaris, G.J.E. Nychas, M. Kom aitis. Analysis of flavonoids and phenolic acids in Greek aromatic plants: investigation of their antioxidant capacity and antimicrobial activity Food Chem., 95 (2006), pp. 664-671.
3) Cardellina, J.H., Fuller, R.W., Gamble, W.R., Westergaard, C., Boswell, J., Munro, M.H.G., Currens, M. Boyd, M.P. (1999). Evolving strategies for the selection de-replication and prioritization of antitumor and HIV inhibitory natural products extracts. (Eds. Bohlin, L. and Bruhn, J.G.) Bioassay Methods in Natural Product Research and Development, Kluwer Academic Publishers, Dordrecht, p.25-36.

4) Chaman Lal and Verma LR: Use of certain bioproducts for insect-pest control. Indian Journal of Traditional Knowledge 2006; 5(1): 79- 82.

5) Francis, D., \& Rita, L. (1986). Rapid colorometric assay for cell growth and survival modifications to the tetrazolium dye procedure giving improved sensitivity and reliability. Journal of Immunological Methods, 89, 271-277. 
6) Gullett, N.P., et al. (2010) Cancer Prevention with Natural Compounds. Seminars in Oncology, 3, 258-281.

7) Kahkonen, M. P., Hopia, A. I., Vuorela, H. J., Rauha, J.-P., Pihlaja, K., Kujala, T. S., et al. (1999). Antioxidant activity of plant extracts containing phenolic compounds. Journal of the Agricultural and Food Chemistry, 47, 3954-3962.

8) Kanatt SR, Chander R and Sharma A, 2010. Antioxidant and antimicrobial activity of pomegranate peel extract improves the shelf life of chicken products. International Journal of Food Science and Technology, 45(2): 216-222.

9) Kaushik JC, Arya Sanjay, Tripathi NN, Arya S: Antifungal properties of some plant extracts against the damping off fungi of forest nurseries. Indian Journal of Forestry 2002; 25: 359-361.

10) Makari, H.K., Haraprasad, N., Patil, H.S. \& Ravikumar, H. (2008). In Vitro Antioxidant Activity of the Hexane and Methanolic Extracts Of Cordia Wallichii And Celastrus Paniculata. The internet J.Aesthetic and Antiaging Medicine., 1: $1-10$.

11) Merghoub, N., Laïla, B., Amzazi, S., Morjani, H., El mzibri, M. (2009). Cytotoxic effect of some Moroccan medicinal plant extracts on human cervical cell lines. Journal of Medicinal Plants Research., 3:1045-1050.

12) Molyneux, P. The use of the stable free radical diphenylpicryl-hydrazyl (DPPH) for estimating antioxidant activity. Songklanakarin J. Sci. Technol. 2004, 26, 211-219.

13) Noda Y, Anzai-Kmori A, Kohono M, Shimnei M, Packer L. Hydroxyl and superoxide anion radical scavenging activities of natural source antioxidants using the computerized JES-FR30 ESR spectromoter system. Biochem. Mol. Biol. Inter. 1997; $42: 35-44$.
14) Osawa T. Postharvest biochemistry. In: Uritani I, Garcia VV, Mendoza, EM, editors. Novel neutral antioxidant for utilization in food and biological systems. Japan: Japan Scientific Societies Press; 1994. p. 241-251. 5.

15) Oyaizu, M. (1986). Studies on products of browning reactions: antioxidative activities of products of browning reaction prepared from glucosamine. Japanese Journal of Nutrition, 44, 307-315.

16) Pierangeli G, Vital $G$ and Rivera W: Antimicrobial activity and cytotoxicity of Chromolaena odorata (L. f) King and Robinson and Uncaria perrottetii (A. Rich) Merr Extracts. J. Medicinal Plants Res 2009; 3(7): 511-518.

17) Pieters, L. Vlietnick, A.J. (2005). Bio-guided isolation of pharmacologically active plant components, still a valuable strategy for the finding of new lead compounds? J. Ethnopharmacol., 100: 57-60.

18) Rice-Evans, C., Miller, N., \& Paganga, G. (1997). Antioxidant properties of phenolic compounds. Trends in Plant Science, 2, 152-159.

19) Rimbach G, Fuchs J, Packer L (2005). Application of nutrigenomics tools to analyze the role of oxidants and antioxidants in gene expression. In: Rimbach G, Fuchs J, Packer L (eds.), Nutrigenomics, Taylor and Francis Boca Raton Publishers, FL, USA, pp. 1-12.

20) Shah BN, et al. (2013) Imp3 unfolds stem structures in pre-rRNA and U3 sno $R N A$ to form a duplex essential for small subunit processing. $R N A 19$ (10):1372-83

21) Vyas GD: Soil Fertility Deterioration in Crop Land Due to Pesticide. Journal of Indian Botanical Society $\quad 1999 ; \quad 78: \quad 177-\quad 178$. 